\title{
Environmental Generation Framework: Case of Environmental Awareness Among Farmers and Senior High School Students for Sustainable Development
}

Isaac Kwaku Adu ( $\sim$ lordadu18@gmail.com)

Jochi Daigaku Chikyu Kankyo https://orcid.org/0000-0002-2541-5005

John Joseph Puthenkalam

Sophia University S J House: Jochi Daigaku S J House

Effah Kwabena Antwi

Natural Resources Canada

Original paper

Keywords: Environmental Generation Framework, environmental awareness, sustainable development, farmers, SHS students

Posted Date: February 9th, 2021

DOl: https://doi.org/10.21203/rs.3.rs-196540/v1

License: (c) (1) This work is licensed under a Creative Commons Attribution 4.0 International License.

Read Full License 
Human-driven environmental changes in the ecosystem have affected ecosystem stability, functions, services, and human well-being (Adu, Tetteh, Puthenkalam, \& Antwi, 2020; Archibald, Staver, \& Levin, 2012; Hautier et al., 2015). The land transition from non-agriculture to agricultural lands is expected to happen in developing countries especially on the African continent base on recent estimates by the world bank where over 200 million hectares of agricultural lands remains unexploited (Byerlee, Stevenson, \& Villoria, 2014; Deininger \& Byerlee, 2011; Laurance, Sayer, \& Cassman, 2014). In their estimation, global arable land is likely to have a net increase of $6 \times 10^{6}$ hectares of land per year (Deininger \& Byerlee, 2011). The IPCC report on land and climate indicates that anthropogenic activities directly affects more than $70 \%$ of the global, ice-free land surface (Arneth et al., 2019).

The principal basis to ensure food security, fresh water source, human livelihood and sustainability, and other ecosystem services is land. This resource continues to play important role in climate change. The rate of agricultural expansion and intensification raises concern about the sustainability of forest, ecosystem function and service, and land degradation (Adu et al., 2020; Boakye-Danquah, Antwi, Saito, Abekoe, \& Takeuchi, 2014). Despite the application of science and technology in the agrarian sector, productivity continues to be low denying farmers a deserving well-being and impeding sustainable development. With more mouths to be fed, slash and burn agriculture, use of inorganic fertilizer, use of agrochemicals, intensive agriculture coupled with farmers' inability to replenish lost nutrients has led to land degradation (Barbier \& Hochard, 2018a, 2018b; Chand, Prasanna, \& Singh, 2011). The low productivity and the increase in population bring doubts about achieving improved environmental well-being, environmental sustainability, sustainable development, food security, and an increase in income on the African continent (Barbier \& Hochard, 2018b; Gupta, 2019).

To ensure that food production does not continue to have a negative impact on the environment and that climate change does not also negatively impact agricultural lands, sustainable agricultural practices have been encouraged especially among small-holder farmers. The capacity to ensure that sustainable farming employs the best land-related adaptation and mitigation responses depends on its natural resource endowment, social, cultural, political, and economic conditions (Garrity, 2020; Puthenkalam, 2016). Sustainable agriculture has centered on four major pillars: human well-being, economic profitability and equity, social equity, and environmental health (Behnassi, Shahid, \& D'Silva, 2011; Castro, Azul, Leal Filho, \& Azeiteiro, 2019; Nandwani, 2016).

Agricultural land-related strategies for climate and weather risk management includes diversifying crops. Drought resistant perennial crops that enhance the quality of soil and moisture retention are grown as an adaptive mechanism. Most farmers include the rearing of livestock as a way of diversifying their enterprise; this increases forage production that adds value to the farm (Agyeman, Asuming-Brempong, \& Onumah, 2014; Watete, Makau, Njoka, AderoMacOpiyo, $\&$ Mureithi, 2016). Sustainable land resource management has proven to deal with land stress, such as extended drought, extreme temperatures, and flooding from climate change (Eckstein, Künzel, Schäfer, \& Winges, 2019). Other agricultural land-related responses to climate change are to increase conservation tillage and shelterbelts (Powlson et al., 2014).

Been abreast of environmental issues and its negative impacts on the three pillars of sustainable development could reduce human-related activities that put the earth in danger, increase environmental well-being, and brightens the next generations' chances of a sustainable future. All pathway to reducing the greenhouse gas emission requires land-related strategies but adaptation and mitigation measures have some barriers and limitations (Debonne, 2019; Shukla et al., 2019). Therefore, the need for environmental education is equally important as any other measures to ensure that environmental well-being and sustainable development are achieved. Studies on both generations has been conducted, yet, it is unclear whether such environmental education should be centered on the current or the next generation. Moreover, none of the studies analyzes environmental awareness level on the two generations from the same data source. The present study seeks to fill this gap.

With the view of ensuring environmental sustainability which could translate into increased income, savings, and investments, this paper analyses perceived environmental knowledge of both the current and future generations. Moreover, the study dives into assessing their sense of environmental responsibility and evaluate how household-heads and Senior High School (SHS) Students perceptions about law and regulations preventing a further spread of the current environmental mess created. 


\subsection{Sustainable development}

Sustainable development has been used in different contexts and fields by business leaders, academia, policymakers, international negotiators, marketers, government agencies, non-governmental organizations, and civic groups. The concept of sustainable development gained global recognition at the UN Conference on Environment and Development (UNCED) held in Rio de Janeiro, Brazil in 1992 (Gudmundsson, Marsden, \& Josias, 2016). The most commonly used and quoted definition of sustainable development is from the Brundtland Commission report on "The World Commission on Environment and Development: Our Common Future" it defines Sustainable development as development that meets the needs of the present without compromising the ability of future generations to meet their own needs (Brundtland, Khalid, Agnelli, Al-Athel, \& Chidzero, 1987).

The definition consists of two key concepts, the concept of "needs" which places the needs of the poor and the most vulnerable as a top priority, and the idea of limiting the level of technology, human activities, and social movement on the environment to achieve the needs of present and that the next generation (Gudmundsson et al., 2016; Puthenkalam, 2016; Searchinger et al., 2019). There has been a conflict in attending to the needs of the present and the next generations. The present generation has within its power to render the earth barren as it seeks to meet its daily needs. This has the potential to impede the ability of the next generation to develop. The increasing awareness of the seriousness of environmental degradation has led many to argue in favour of environmental education to conserve the earth's resources to meet the need of both generations. This could help achieve the three most important elements (environment, society, and economy) of sustainable development.

\subsection{Environmental awareness through environmental education}

Recently, global environmental issues have received great attention due to the increase in global problems relating to pollution, depletion of natural resources, land degradation, and climate change (DeSombre, 2017; Mason, Shires, Arwood, \& Borst, 2017) Other environmental problems, such as acid rain, urban sprawl, waste disposal, etc., have affected nature and mankind (Montoneri, Mainero, Boffa, Perrone, \& Montoneri, 2011; Padi, Domfeh, Takrama, \& Opoku, 2013). The desire to develop in all dimensions of life characterized by the exploitation of natural resources has led to severe degradation of the environment (Adu et al., 2020; Kharkongor \& Passah, 2012). The quest for development has modified the land surface in the last 10,000 years; forest land has been reduced whiles cropland and residential area have increased to meet the increasing demand of the growing population (Li et al., 2018; Liu et al., 2018; X.-P. Song, 2018).

The IPCC's (2019) report indicates that 70\% of the world's landscape has been affected by human activities and agricultural intensification; these activities generated land degradation (Debonne, 2019; Shukla et al., 2019) . Data from the World Bank (2019), indicates that crop production increased by $240 \%$ between 1961 and 2017. Agricultural, forestry, and other related land use activities together emit around $13 \%$ of carbon dioxide, $44 \%$ of methane, and $82 \%$ of nitrous oxide during the $2007-2016$ period representing a total of $23 \%$ of all greenhouse emission caused by anthropogenic factors (Debonne, 2019; Shukla et al., 2019).

Land-related adaptation and mitigation strategies continue to undergo changes to deal with the dynamics of climate change. There are limits to these measures and hence, the need to instill environmentalism in the younger generation to reduce activities that increase the emission of greenhouse gases and pollute the environment. This can be achieved by the creation of awareness through the various sources of environmental information transmission systems especially through the formal education system.

A study conducted to assess the role of the national level of prosperity, environmental degradation and economic growth on an individual's likelihoods of environmental consciousness concluded that the higher the level of a nation's wealth the lesser the likelihood of individual's concern for the environment, whereas, economic development and increase in environmental degradation ignite individual-level pro-environmental concern (Givens \& Jorgenson, 2011).

Rural dwellers' livelihood depends mainly on farming, and this is the major link between the dwellers and land. A study to examine farmers' environmental awareness and attitude towards environmental degradation, found that perception of the seriousness of environmental degradation had a positive influence on their awareness, concern, and attitude toward environmental degradation (Wu \& Mweemba, 2010). Therefore, the greater the level of environmental consciousness among the farmers the higher their involvement in land management activities. This also enhances their capacity to take the decision to improve and reverse land degradation (Coelho, Pereira, Cruz, Simões, \& Barata, 2017; $\mathrm{Wu} \&$ Mweemba, 2010). In doing so, it could have a positive impact on land leading to an improvement in environmental sustainability. 
Literature on environmental consciousness/awareness among both generations showed inconclusive results with regards to gender. A research on environmental consciousness/awareness among higher primary school teachers in the city of Mysore, India, female teachers were found to be more knowledgeable than their male counterparts (Larijani, 2010). An opposite result was reported in a similar study, whiles, results among male and female in other studies did not differ significantly, i.e., gender is reported not to be a significant determinant of environmental knowledge and behavior (Sengupta, Das, \& Maji, 2010).

In achieving sustainable environmental practices, Ahmad, Noor \& Ismail (2015); established a weak relationship between students' level of knowledge, attitudes, and sustainable environmental practices (Ahmad, Noor, \& Ismail, 2015). Most studies are gradually pointing to the youth as a target cohort for environmental education whiles others think otherwise (Delia \& Krasny, 2018; Van Cauwenberg, De Bourdeaudhuij, Clarys, De Geus, \& Deforche, 2019). Economic development has taken place without regard to environmental sustainability. Environmental degradation is on the rise as land-cover change is inevitable but to achieve sustainable development, environmental sustainability is a must. Against this background, this research does a comparative study of the level of perceived environmental knowledge of both generations with the aim of identifying which of these generations should be the focus to ensure that environmental well-being and sustainable development are achieved.

\subsection{Environmental education among the youth}

Surveys have registered an increase in people's environmental awareness (Yucedag, Kaya, \& Cetin, 2018; Zhang, Wang, \& You, 2015). All researches conducted either gave preference to the younger generation (Delia \& Krasny, 2018; Staples, Larson, Worsley, Green, \& Carroll, 2019), or the older generation (Pelusi et al., 2019; Van Cauwenberg et al., 2019), this does not provide a platform for comparison to make an informed decision as to which of the generations deserves an in-depth environmental education to save the ailing environment.

Moreover, to ensure intergenerational responsibility and entitlement, and sustainable development, it is expected that the current generation hands over a sound environment that will not compromise or threaten the livelihood of the next generation. Therefore, the younger generation is also expected to know more and be more concerned about the environment they are inheriting than their parents (English \& Carstensen, 2015; Y. Song, Qin, \& Yuan, 2019).

With inspirations and motivations from the idea that highly engaged and environmentally inspired youth mostly become agents of change for social movements, many researches have evaluated the level of environmental awareness of the young generation (Fulford \& Thompson, 2013; Grimmette, 2014). A study conducted for the youth in Canada by Dittmer and Riemer (2012), was influenced by five community psychological project concepts namely: stakeholder participation, social justice, ecological and systems thinking, praxis, and empirical grounding. The project had among other objectives to focus intensively on the youth who could also influence those around them to change and re-think their current unfavorable environmental behavior to pro-environmental behavior. The project's outcomes, measured through evaluative research indicate a great impact on the project's quality and changed outcomes experienced by the youth.

Results from another study to evaluate the impact of urban environmental education programs patronized by high school students in Bronx, New York, in environmental stewardship, environmental skills development, and environmental monitoring indicates a successful outcome in nurturing ecological mindset among the youth (Kudryavtsev, Krasny, \& Stedman, 2012). In a non-formal environmental education for adults conducted by Pudin (2011), in Sabah, Malaysia, revealed that all activities and programs implemented were found to have impacted positively and increased awareness on environmental issues, protection, and problems. But this is not enough to conclude that the young or the current generation should be targeted without analyzing the two generations using the same parameters from the same data source.

In all the studies conducted, environmental consciousness is on the rise but all the study was done using different questionnaire and methodology. Assessing the level of environmental consciousness of both generations using the same survey and method is lacking in the literature. Some research suggests that having access to a reliable environmental source of education contributes to pro-environmental behaviors (Bolderdijk, Gorsira, Keizer, \& Steg, 2013). Yet, it is not clear whether environmental education should be more centered on the current generation (under whose tenure the environment continues to deteriorate rapidly) or on the next generation who are more curious about the environment. To investigate the possible impact of an environmentally educated youth (being young) on environmental sustainability and make a comparison between the old and the next generations, this research explain the role of perception of time using the socioemotional selectivity theory for such comparison. 


\subsection{Socioemotional selectivity theory and environmental generation framework}

Higher environmental awareness could bring about pro-environmental behavior leading to environmental responsibility and eventually, increased environmental well-being. In the pursuit of pro-environmental behavior, being young or old plays an important role as claimed by the socioemotional selectivity theory proposed by Carstensen and colleagues. The theory argues that the perception of time plays a vital role in the selection process and pursuit of social goals, that is; time is viewed as an important factor in the changes that happen across a person's lifetime (Carstensen, 1992; Carstensen, Fung, \& Charles, 2003; Zheng \& Wang, 2020).

The theory categorizes social motives into two - those goals related to the acquisition of knowledge and those goals associated with the regulation of emotions. The theory claims that the younger generation perceives time as more openminded, and thus the acquisition of knowledge-related goals is prioritized. In contrast, the older generation perceives time as a limited commodity and, as such, prioritize emotion-related goals over the acquisition of knowledge-related goals (Min, 2020; Zheng \& Wang, 2020).

As is typical in the younger generation, the future is perceived as long and imprecise, therefore, future-oriented motives related to the acquisition of knowledge, gathering information, and expanding horizons are prioritized immediately over emotional glory. Base on this theory, it would be just to say that a youthful generation that is conscious of their environment and the consequences of the human activities towards the environment would prioritize the acquisition and gathering of knowledge to save the environment from deteriorating.

Hence, this study proposes the Environmental generation framework that would spark environmentalism among the younger generation or to raise an environmental generation. Environmental generation framework moves alongside the socioemotional selectivity theory, but it concentrates on the younger generation rather than the older individuals who mostly prioritize emotion-related goals over knowledge-related goals (refer to figure 1). This does not mean that environmental education towards the older generation should not be encouraged but rather the concentration should be on the younger ones.

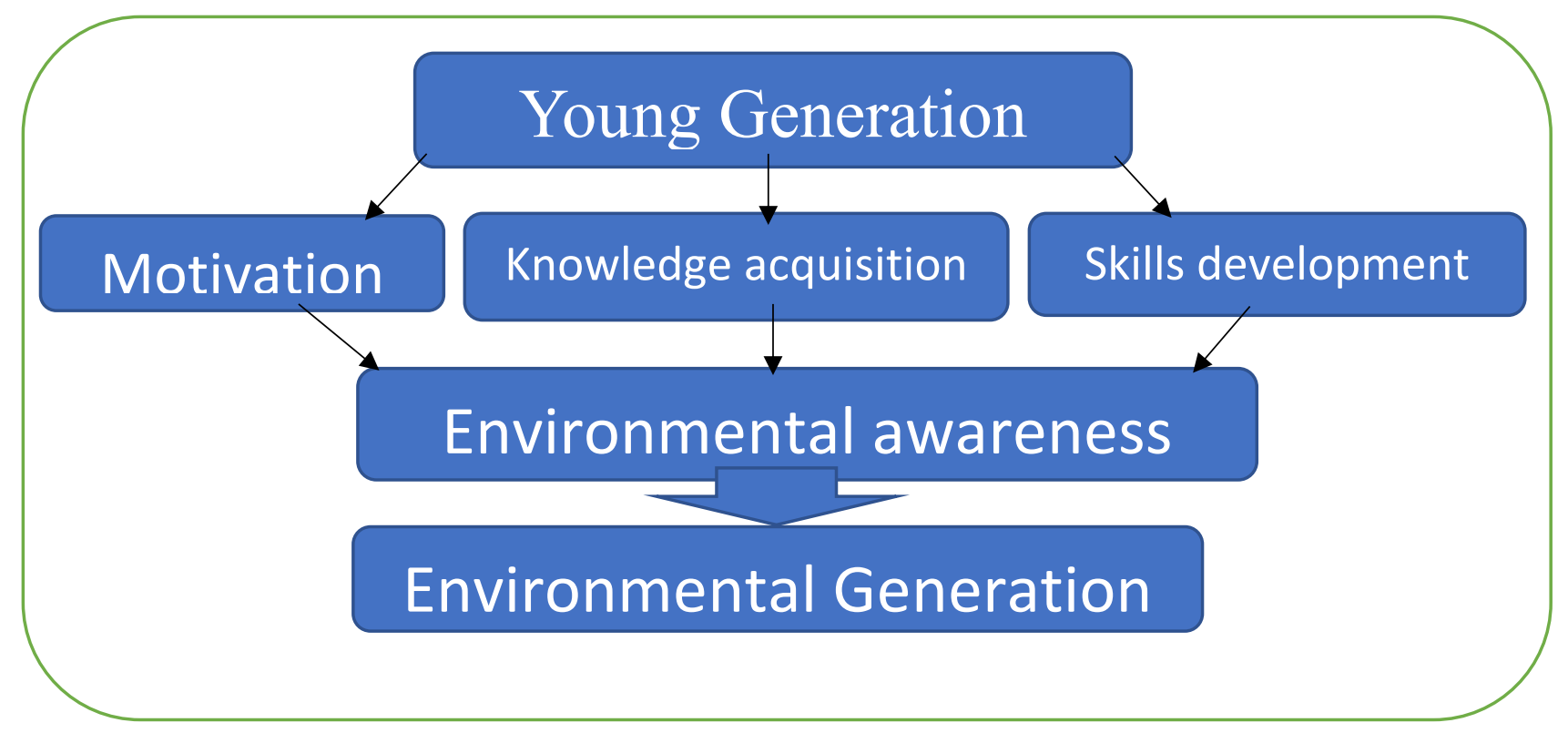

Figure 1: Environmental Generation framework

\section{Material and method}

Data was collected through the administration of questionnaire to respondents of the study area (Abuakwa North and South Municipalities). Abuakwa North and South Municipalities is home to a mixture of people from a diverse background. The household was sampled from 20 communities, 10 from each municipality. The study area was stratified into electoral areas to have a full representation of the communities and the household was randomly selected. Therefore, the stratified random sampling method was employed to identify the 388 households with 376 questionnaires fully completed and all questions fully answered. The overall valid response from the respondents/household sampled is 97 per cent based on the 388 administered. In this way, sampling the population of the two municipalities was divided into smaller groups or is partitioned into subpopulations known as strata. In this research the strata are referred to as the 
electoral areas in the district and municipal administration of Ghana and members of this strata shared the same or similar characteristics or attributes. The same questionnaire was administered to 200 Senior High School Students (SHS). The SHSs selected are Ofori Panin SHS, Abuakwa North Municipality; Kyebi SHS/Tech, Abuakwa South Municipality; Presby SHS, Fanteakwa North District; and Presby SHS, Fanteakwa South District; all of the Eastern Region of Ghana.

In applying this new framework, the author tests the hypothesis derived from the Environmental Generation Framework regarding the effect of an educated younger generation on environmental awareness, environmental responsibility, and level of preparedness to reverse and restore environmental degradation. Using a Likert scale the survey collected data on their general perceived environmental knowledge, their views on laws and regulations about the environment, and their sense of environmental responsibility. Analysis of the data was performed using Microsoft excel, SPSS and STATA.

\subsection{Linear Probability Model of Perceived Environmental Knowledge}

To determine what drives perceived environmental knowledge of the sampled population, we used the Linear Probability Model (LPM). This is because the outcome variable (perceived environmental knowledge) of the model is a dummy variable for both groups, and every member of the group has the same value for the dependent variable. In this case, the coefficient of the group dummy variable cannot be estimated in logit or probit models but rather in the linear probability model (Deke, 2014; Caudill, 1988). With the outcome variable as a dummy, the estimation can be perform using the Ordinary Least Square (OLS) equation in Linear probability Model. Despite the uniqueness of probit and logit for estimating dummy dependent variable models, OLS in the LPM is still used (Horrace \& Oaxaca, 2006; Lewbel et al., 2012).

The variables used in the Ordinary Least Square or the Linear Probability Model specification are perceived environmental knowledge as dependent variable with age, gender, level of formal education, years of farming experience, marital status, religious denomination, ethnicity, municipality, and income as covariates in the household heads (farmers) group as shown in table 1 The covariates used in the SHS group are age, gender, the region of origin, the program of study, ethnicity, religious denomination, parents' educational level and SHS grade as shown in table 2. The dependent variables take the value of 1 if the farmer/SHS student meet the acceptable score of perceived environmental knowledge and 0 otherwise. The OLS in LMP equation used is as follows:

$$
y_{i}=\beta_{0}+\beta_{1} x_{i}+\cdots+\beta_{k} \mathrm{X}_{\mathrm{i}}+u_{i}
$$

where $y_{i}$ is a dummy variable equal to 1 if farmer/SHS student $i$ meets the acceptable score of perceived environmental knowledge and 0 otherwise, while $u_{i}$ is the error term.

Below are the dependent variables and the covariate used for the household heads group (farmers).

Perceived Environmental Knowledge $=\beta_{0}+\beta_{1}$ age $+\beta_{2}$ gender $+\beta_{3}$ marital status +

$\beta_{4}$ level of formal education $+\beta_{5}$ years of farming experience $+\beta_{6}$ religious denomination

$+\beta_{7}$ ethnicity $+\beta_{8}$ municpality $+\beta_{9}$ income $+\mu$

The parameters of interest are $\beta_{1}, \beta_{2}$ and $\beta_{4}$

And that of the SHS students is as follows:

Perceived Environmental Knowledge $=\beta_{0}+\beta_{1}$ age $+\beta_{2}$ gender $+\beta_{3}$ region of origin +

$\beta_{4}$ program of study $+\beta_{5}$ ethnicity $+\beta_{6}$ religious denimination $+\beta_{7}$ Father's education

$+\beta_{8}$ mother's education $+\beta_{9}$ SHS grade $+\mu$

The parameters of interest are $\beta_{1}, \beta_{2}$ and $\beta_{9}$ 


\subsubsection{Definition of variables: Linear Probability Model of Perceived Environmental Knowledge}

\subsubsection{Dependent/outcome variables}

$y_{i}$ is a dummy variable equal to 1 if farmer/SHS student $i$ meets the acceptable score of perceived environmental knowledge and 0 otherwise, while $u_{i}$ is the error term.

\subsubsection{Explanatory/independent/control variables for the household heads (farmers) group}

Age: Equals 1 if farmers' age is 18 to 40 years, 2 if farmers' age is 41 to 60 years, 3 if farmers' age is 61 to 80 years, and 4 if farmers' age is 81 years and over.

Gender: is a dummy variable equal to 1 if the farmer is a male and 0 if a female. It is expected that females become more knowledgeable than males due to their active engagement in household oriented pro-environmental activities.

Level of education: Equals 1 if the farmer has no education, 2 if farmer has a primary education, 3 if farmer has Junior High School education, 4 if farmer has Senior High School education, 5 if farmer has tertiary education. The study predicts a positive relationship between this variable and perceived environmental knowledge since an educated farmer is likely to know more about pro-environmental activities and make informed technical and economical choices to conserve, reverse and restore degraded land.

Years of farming experience: Equals 1 if farmers' years of farming experience is 1 month to 10 years, 2 if farmers' years of farming experience is 11 to 20 years, 3 if farmers' years of farming experience is 11 to 30 years and 4 if farmers' age is 31 years and over. A positive relationship is expected between this variable and perceived environmental knowledge due to their experience in working with the land.

Marital status: Equals to 1 if farmer is single, 2 if farmer is monogamously married, 3 if farmer is polygamously married, 4 if farmer is widow, 5 if farmer is separated/divorced, and 6 if farmer is none of the above.

Ethnicity: Equals to 1 if farmer does not belong to any ethnic group, 2 if farmer belongs to the Akan ethnic group, 3 if farmer belongs to the Ewe ethnic group, 4 if farmer belongs to the Ga-Dangme ethnic group, 5 if farmer belongs to the Dagbani ethnic group and 6 if farmer belongs to the Frafra/Grusi ethnic group, 7 if farmer belongs to the Nzema ethnic group, 8 if farmer belongs to the Wali/Dagari ethnic group, 9 if others.

Religious denomination: Equals to 1 if farmer has no religion, 2 if farmer belongs to the Orthodox, 3 if farmer belongs to the Protestants, 4 if farmer belongs to the Pentecostals, 5 if farmer belongs to Charismatic, 6 if farmer belongs to other Christians sects and 7 if farmer belongs to the Islamic religion, 8 if farmer belongs to the Traditional religion, 9 if others.

Municipality: is a dummy variable equal to 1 if farmer is from Abuakwa North municipality and 0 otherwise.

Income: Equals 1 if a farmer's annual income is below the lower poverty line of GH $\$ 982.2$ (\$258.47); is equal to 2 if a farmer's annual income is below the upper poverty line of $\mathrm{GH} \phi 1,760.8$ (\$463.37) using the exchange rate of $\$ 1=\mathrm{GH} \phi$ 3.8 (January, 2016) per adult equivalent per year and equals to 3 if a farmer's annual income is above the upper poverty line.

\subsubsection{Explanatory/independent/control variables for the SHS group}

Age: Equals 1 if SHS students' age is 14-15years, 2 if SHS students' age is 16-17 years, 3 if SHS students' age is 1820 years.

Gender: is a dummy variable equal to 1 if SHS student is female and 0 if a male. It is expected that females become more knowledgeable than males due to their active engagement in household oriented pro-environmental activities.

Region of origin: Equals 1 if SHS student comes from Eastern region, 2 if SHS student comes from Greater Accra region, 3 if SHS student comes from Central region, 4 if SHS student comes from Western region, 5 if SHS student comes from Volta region, 6 if SHS student comes from Bono region, 7 if SHS student comes from Northern region, 8 if SHS student comes from Upper East region, 9 if SHS student comes from Ashanti region, and 10 if SHS student comes from other regions other than the ones stated earlier.

SHS grade: SHS grade was categorized in SHS one, two, and three. We predicted a positive relationship between this variable and perceived environmental knowledge since a subject called "Environmental Studies" has been thought at all levels of education in Ghana. Therefore, SHS students are expected to be knowledgeable about environmental issues and problems.

Program of study: Equals to 1 if SHS students' program of study is General Arts, 2 if SHS students' program of study is Business Studies, 3 if SHS students' program of study is General Science, 4 if SHS students' program of study is Home Economics, 5 if SHS students' program of study is Visual Arts, 6 if SHS students' program of study is Agricultural Science, and 7 if SHS students' program of study is Technical Studies. 
Ethnicity: Ethnicity was categorized in Akan, Ewe, Ga-Dangme, Dagbani, Frafra/Grusi, Nzema, Wali/Dagari, and others. Ethnicity is equal to 1 if SHS student does not belong to any ethnic group, 2 if SHS student belongs to the Akan ethnic group, 3 if SHS student belongs to the Ewe ethnic group, 4 if SHS student belongs to the Ga-Dangme ethnic group, 5 if SHS student belongs to the Dagbani ethnic group and 6 if SHS student belongs to the Frafra/Grusi ethnic group, 7 if SHS student belongs to the Nzema ethnic group, 8 if SHS student belongs to the Wali/Dagari ethnic group, 9 if others.

Religious denomination: Equals to 1 if SHS student has no religion, 2 if SHS student belongs to the Orthodox, 3 if SHS student belongs to the Protestants, 4 if SHS student belongs to the Pentecostals, 5 if SHS student belongs to Charismatic, 6 if SHS student belongs to other Christians sects and 7 if SHS student belongs to the Islamic religion, 8 if SHS student belongs to the Traditional religion, 9 if others.

Father's and mother's level of education: The education level of parents of the SHS students was categorized into none, primary education, Junior High school, Senior High school, Tertiary, and others. We predicted a positive relationship between this variable and perceived environmental knowledge since an educated parent can educate their wards on pro-environmental behaviors.

\subsection{Cumulative percentage of the performance of perceived level of environmental knowledge}

In assessment studies and /or experience surveys, one of the most appropriate and useful measure to deal with ordinal scale data is the cumulative percentage (Al Rubaish, 2010; Göb et al., 2007). Based on deductions from assessment studies conducted towards the furtherance of academic programs and taking inspiration from the National Commission for Assessment and Academic Accreditation (NCAAA) and some global repute institutions, Al Rubaish, Wosornu, and Dwivedi (2011), adopted the cumulative percentage as the more appropriate measure. As an advantage over the arithmetic mean, median, and the first quartile, it is a simple and straightforward measure, easy to understand, and clearer to non-statisticians (Al Rubaish, 2011b). It also helps to quantify any improvement or otherwise in performance over a period of time and finally, it assists in identifying where improvement is needed (Al Rubaish, 2011a, 2011b). To ensure quality, an enhanced satisfactory score was re-set from $75 \%$ to at least $80 \%$.

The cumulative percentage of perceived environmental knowledge group the score of the sampled population into three groups. Those who scored below $60 \%$ were categorized as those who require improvement (poor), while those who score above $60 \%$ but less than $80 \%$ and those who had above $80 \%$ were combined to form the acceptable score. To determine an acceptable score, parametric and non-parametric measures such as arithmetic mean, median, first quartile, and cumulative percentage have been used as analytical tools in such assessment. But for analysis using the linear probability model, the good and excellent scores were combined and named as acceptable score.

The overall performance was described in three bands as follows:

\begin{tabular}{ll}
\hline Less than $60 \%$ & Improvement required (Poor) \\
$60 \%-79 \%$ & Acceptable (Good) \\
$80 \% \&$ above & High quality (Excellent) \\
\hline
\end{tabular}

\section{Results}

\subsection{Demographic characteristics}

Below is the demographic information on the two cohorts. Tables $1 \& 2$ Error! Reference source not found. presents the demographic features of the household heads and SHS students respectively. Of the total, male households' heads are 312 , representing $82.98 \%$, with 64 been female representing $17.02 \%$. Universally, males are known to be the head of a household though females also assume this role in the absence of the male or where the female is either a widow or never married but have children. The age of household members was grouped into four categories, namely: 18 to 40 years, 41 to 60 years, 61 to 80 years, and above 80 years. Those in the age bracket of $18-40$ represent $16.49 \%$, with the 41-60 years been $42.02 \%$ of the sampled farmers, $38.30 \%$ were within the age bracket of $61-80$ years whiles those above 80 years were $3.19 \% .83 .51 \%$ of the respondents are farmers above 40 years, this suggests that older people are more involved in the agrarian sector of the study area than the younger ones. It is expected that they might have worked on their farms for so many years and should be knowledgeable about the effects on their work of the environment and vice versa. Among the household heads/farmers cohort, 14.63 percent had no formal education, 43.35 percent had primary level of education whilst 22.61 percent had junior high school education. Also, 16.49 percent of the respondents had senior high school education, with only 2.93 percent having had tertiary education. It is expected that the 
educational level of respondents would have a significant influence on their perceived level of knowledge on environmental issues.

Their ages were grouped into 14-15 years, 16-17 years, and 18-20 years. The highest number of respondents representing $66.50 \%$ were students between $16-17$ years followed by the age group $18-20$ years, with $26 \%$ and $14-15$ years with $7.5 \%$. Males represent $52 \%$ and females were $48 \%$. The student respondents were studying seven (7) different programs, namely: general arts $(17 \%)$, business studies $(17 \%)$, general science $(17 \%)$, home economics $(16.5 \%)$, visual arts $(17 \%)$, agricultural science $(7.5 \%)$ and technical studies $(8 \%)$. There were fifty (50) students each from Ofori Panin SHS in the Abuakwa North Municipality, Kyebi SHS in the Abuakwa South Municipality, Presbyterian SHS in the Fanteakwa North District, and Presbyterian SHS in the Fanteakwa South District, all of the Eastern Region of Ghana. It is expected that the educational level of parents would impact significantly on their wards level of environmental knowledge. In this regard, data on parents' educational level was collected as follows: $28 \%$, $34.5 \%$ and $26 \%$ of the student's father had completed junior high, senior high, and the tertiary respectively as against $32.5 \%, 36 \%$, and $13.5 \%$ of their mothers who had completed for Junior high, senior high and the tertiary respectively,

\subsection{Independent sample t-test of household heads and SHS students}

An independent samples t-test was conducted to compare the means of two independent groups, i.e., male and female on ten environmental dimensions to determine whether there is statistical evidence that the associated population means are significantly different. The null hypothesis $\left(\mathrm{H}_{0}\right)$ that there is no significant difference between males and females will be rejected if the value of the observed T-Test exceeds the critical values. Tables $3 \& 4$ presents the results of the independent T-Test of the two groups.

Among the household heads group, the female $(\mathrm{N}=64)$ was associated with a performance $\mathrm{M}=2.48(\mathrm{SD}=0.713)$. By comparison, the male $(\mathrm{N}=312)$ was associated with a numerically better performance $\mathrm{M}=2.73(\mathrm{SD}=0.820)$. Levene's test for equality of variances showed no violation, $\mathrm{F}(374)=.015, \mathrm{p}=.902$. The independent samples t-test was associated with a statistically significant effect, $\mathrm{t}(374)=2.27, \mathrm{p}=0.024$. Thus, males were associated with statistically significant knowledge of environmental issues and problems than females. The effect size of comparing two means is measured by Cohen's $\mathrm{D}^{1}$, this was estimated at .33 . Similar interpretation is given to all the other nine dimensions.

Also, an independent sample t-test was conducted to examine gender differences in the level of knowledge on environmental issues and problems among SHS students. The assumption of homogeneity of variances was tested and satisfied via the Levene's F Test, $\mathrm{F}(198)=3.14, \mathrm{p}=.078$. Results indicates that males $(\mathrm{M}=3.45, \mathrm{SD}=.780)$ scored higher than females $(\mathrm{M}=3.19, \mathrm{SD}=.725), \mathrm{t}(198)=-2.40, \mathrm{p}=0.017$, Cohen's $\mathrm{D}=.35$. The results among the SHS students confirms the trend in the household heads. The overall results are contrary to some earlier reports that suggest that gender is not a significant determinant of environmental knowledge and behavior (Sengupta et al., 2010). But it also confirms previous findings that males report higher environmental awareness than females.

\subsection{Cumulative percentage of the performance of perceived level of environmental knowledge}

The overall cumulative performance of perceived environmental knowledge results shows that $23.67 \%, 31.91 \%$, and $44.41 \%$ of households' heads had a poor, good, and excellent performance, respectively. Compared to the performance of SHS students of $20.50 \%, 26.50 \%$, and $53 \%$, the SHS students performed better.

Drawing inspiration from the fact that environmental awareness largely depends on motivation, knowledge, and skills, the available data from Tables 5 and 6 revealed that the younger generation has a higher level of environmental awareness. Besides, a summation of the acceptable score (good and excellent scores) of both groups shows SHS students obtained a higher score of $79.50 \%$ compared to $76.32 \%$ of the household heads. Even among the household heads, scores show that the younger age group of 18-40 demonstrated a high level of knowledge with an acceptable score of $83.87 \%$ compared to $75.32 \%$ of the older $41-60$-year group, much older $75 \%$ of the $61-80$-year group and $66.66 \%$ of the oldest group of the above 80 years. Using the cumulative percentage performance criteria, it can deduce that the younger generation are more knowledgeable than the older.

As the performance of the SHS students is driven by their level of knowledge acquired through the formal education system strengthened by motivation, household heads (farmers) derived most of their knowledge from the continuous practices of farming activities. The results from table 5 revealed that those with no formal education had a higher

${ }^{1}$ Cohen's D is known to be the ratio of the difference between two means divided by the standard deviation (Cohen, 1992) 
acceptable score of $85.64 \%$ (sum of good and excellent scores) compared to those who had received a formal educationprimary with $77.3 \%$, JHS with $72.95 \%$, SHS with $72.58 \%$, and tertiary with $63.63 \%$.

Table 1: Demographic characteristics of sampled household heads of Abuakwa North and South municipalities

\begin{tabular}{|c|c|c|}
\hline Parameter & Frequency & Percent \\
\hline Total respondent & 376 & 100.00 \\
\hline $\begin{aligned} \text { Gender: } & \text { Male } \\
& \text { Female }\end{aligned}$ & $\begin{array}{c}312 \\
64\end{array}$ & $\begin{array}{l}82.98 \\
17.02\end{array}$ \\
\hline \multicolumn{3}{|l|}{ Age } \\
\hline $18-40$ & 62 & 16.49 \\
\hline $41-60$ & 158 & 42.02 \\
\hline $61-80$ & 144 & 38.30 \\
\hline $81+$ & 12 & 3.19 \\
\hline \multicolumn{3}{|l|}{ Level of Education } \\
\hline None & 55 & 14.63 \\
\hline Primary school & 163 & 43.35 \\
\hline Junior High & 85 & 22.61 \\
\hline Senior High & 62 & 16.49 \\
\hline Tertiary & 11 & 2.93 \\
\hline \multicolumn{2}{|l|}{ Marital Status } & 8.51 \\
\hline Monogamously Married & 270 & 71.81 \\
\hline Polygamously Married & 14 & 3.72 \\
\hline Widowed & 43 & 11.44 \\
\hline Separated/Divorced & 17 & 4.52 \\
\hline \multicolumn{3}{|l|}{ Religious Denomination } \\
\hline Orthodox Christians & 98 & 26.06 \\
\hline Protestant Christians & 44 & 11.70 \\
\hline Pentecostals Christians & 101 & 26.86 \\
\hline Charismatic Christians & 71 & 18.88 \\
\hline Other Christians & 28 & 7.45 \\
\hline Islam & 13 & 3.46 \\
\hline Traditionalist & 4 & 1.06 \\
\hline Others & 5 & 1.33 \\
\hline \multicolumn{3}{|l|}{ Ethnicity } \\
\hline Akan & 247 & 65.69 \\
\hline Ewe & 51 & 13.56 \\
\hline Ga-Dangme & 53 & 14.10 \\
\hline Dagbani & 1 & 0.27 \\
\hline Frafra/Grusi & 5 & 1.33 \\
\hline Nzema & 1 & 0.27 \\
\hline Wali/Dagari & 7 & 1.86 \\
\hline Others & 11 & 2.93 \\
\hline
\end{tabular}

Data is presented as a figure and percentage. Source: Created by the author from fieldwork (2019) 
Table 2: Demographic information of sampled Senior High Schools students

\begin{tabular}{|c|c|c|c|c|}
\hline Parameter & \multicolumn{2}{|c|}{ Frequency } & \multicolumn{2}{|c|}{ Percent } \\
\hline Total respondent & \multicolumn{2}{|r|}{200} & \multicolumn{2}{|c|}{100} \\
\hline \multicolumn{5}{|l|}{ Age: } \\
\hline $14-15$ & \multicolumn{2}{|r|}{15} & \multicolumn{2}{|c|}{7.50} \\
\hline $16-17$ & \multicolumn{2}{|r|}{133} & \multicolumn{2}{|c|}{66.50} \\
\hline $18-20$ & \multicolumn{2}{|r|}{52} & \multicolumn{2}{|c|}{26.00} \\
\hline \multicolumn{5}{|l|}{ Gender: } \\
\hline Female & \multicolumn{2}{|r|}{104} & \multicolumn{2}{|c|}{52.00} \\
\hline Male & \multicolumn{2}{|r|}{96} & \multicolumn{2}{|c|}{48.00} \\
\hline \multicolumn{5}{|l|}{ Regions: } \\
\hline Eastern & \multicolumn{2}{|r|}{98} & \multicolumn{2}{|c|}{49.00} \\
\hline Greater Accra & \multicolumn{2}{|r|}{48} & \multicolumn{2}{|c|}{24.00} \\
\hline Central & \multicolumn{2}{|r|}{13} & \multicolumn{2}{|c|}{6.50} \\
\hline Western & & 1 & & 50 \\
\hline Volta & & 21 & & .50 \\
\hline Bono & & 4 & & 00 \\
\hline Northern & & 1 & & 50 \\
\hline Upper East & & 7 & & 50 \\
\hline Ashanti & & 7 & & 50 \\
\hline Senior High Schools & & & & \\
\hline Ofori Panin SHS & & 50 & & .00 \\
\hline Kyebi SHS/Tech & & 50 & & .00 \\
\hline Presby SHS, Begoro & & 50 & & .00 \\
\hline Presby SHS, Osino & & 50 & & .00 \\
\hline Program of study: & & & & \\
\hline General Arts & & 34 & 17. & \\
\hline Business Studies & & 34 & & .00 \\
\hline General Science & & 34 & & .00 \\
\hline Home Economics & & 33 & & 50 \\
\hline Visual Arts & & 34 & & 00 \\
\hline Agricultural Science & & 15 & & 50 \\
\hline Technical & & 16 & & 00 \\
\hline Religious Denomination & & & & \\
\hline Orthodox Christians & & 103 & & .50 \\
\hline Pentecostals Christians & & 45 & & .50 \\
\hline Charismatics Christians & & 16 & & 00 \\
\hline Other Christians & & 19 & & 50 \\
\hline Islam & & 14 & & 00 \\
\hline Traditionalist & & 1 & & 50 \\
\hline Others & & 2 & & 00 \\
\hline Parent's Education & Father & Mother & Father & Mother \\
\hline None & 7 & 15 & 3.50 & 7.50 \\
\hline Primary education & 12 & 19 & 6.00 & 9.50 \\
\hline Junior High School & 56 & 65 & 28.00 & 32.50 \\
\hline Senior High School & 69 & 72 & 34.50 & 36.00 \\
\hline Tertiary & 52 & 27 & 26.00 & 13.50 \\
\hline Others & 4 & 2 & 2.0 & 1.00 \\
\hline
\end{tabular}

Source: Author's own from fieldwork. Data is presented as a figure and percentage 
Table 3: Independent sample t-test of household heads

\begin{tabular}{|c|c|c|c|c|c|c|c|c|}
\hline \multirow[t]{2}{*}{ Dimension } & \multicolumn{2}{|c|}{ Levene's Test } & \multirow[t]{2}{*}{ Gender } & \multirow[t]{2}{*}{ Mean } & \multirow{2}{*}{$\begin{array}{l}\text { Standard } \\
\text { Deviation }\end{array}$} & \multirow[t]{2}{*}{ P-value } & \multirow[t]{2}{*}{$t$} & \multirow[t]{2}{*}{ Cohen D } \\
\hline & $F$ & Sig & & & & & & \\
\hline \multirow{2}{*}{$\begin{array}{l}\text { Environmental issues and } \\
\text { problems }\end{array}$} & \multirow[t]{2}{*}{.015} & \multirow[t]{2}{*}{.902} & Male & 2.73 & .820 & \multirow[t]{2}{*}{.024} & \multirow[t]{2}{*}{2.266} & \multirow[t]{2}{*}{0.33} \\
\hline & & & Female & 2.48 & .713 & & & \\
\hline \multirow[t]{2}{*}{ Land degradation } & \multirow[t]{2}{*}{1.110} & \multirow[t]{2}{*}{2.93} & Male & 2.81 & .852 & \multirow[t]{2}{*}{.002} & \multirow[t]{2}{*}{3.070} & \multirow[t]{2}{*}{0.43} \\
\hline & & & Female & 2.45 & .834 & & & \\
\hline \multirow[t]{2}{*}{ Urban Sprawl } & \multirow[t]{2}{*}{.013} & \multirow[t]{2}{*}{.908} & Male & 2.76 & .825 & \multirow[t]{2}{*}{.015} & \multirow[t]{2}{*}{2.447} & \multirow[t]{2}{*}{0.36} \\
\hline & & & Female & 2.48 & .734 & & & \\
\hline \multirow[t]{2}{*}{ Water Pollution } & \multirow[t]{2}{*}{.536} & \multirow[t]{2}{*}{.465} & Male & 2.77 & .878 & \multirow[t]{2}{*}{.009} & \multirow[t]{2}{*}{2.641} & \multirow[t]{2}{*}{0.37} \\
\hline & & & Female & 2.45 & .853 & & & \\
\hline \multirow[t]{2}{*}{ Air Pollution } & \multirow[t]{2}{*}{2.106} & .148 & Male & 2.86 & .829 & .002 & 3.151 & 0.43 \\
\hline & & & Female & 2.50 & .836 & & & \\
\hline Biodiversity & .868 & .352 & Male & 2.81 & .850 & .001 & 4.017 & 0.57 \\
\hline & & & Female & 2.34 & .801 & & & \\
\hline Sustainability & .059 & .808 & Male & 2.73 & .825 & .020 & 2.336 & 0.34 \\
\hline & & & Female & 2.47 & .712 & & & \\
\hline Watershed management & 1.561 & .212 & Male & 2.81 & .848 & .001 & 3.761 & 0.51 \\
\hline & & & Female & 2.38 & .826 & & & \\
\hline Conservation of natural resources & .001 & .980 & Male & 2.71 & .822 & .029 & 2.191 & 0.31 \\
\hline & & & Female & 2.47 & .734 & & & \\
\hline Wetlands & .045 & .833 & Male & 2.63 & .909 & .032 & 2.155 & 0.31 \\
\hline & & & Female & 2.36 & .843 & & & \\
\hline
\end{tabular}


Table 4: Independent sample t-test of SHS students

\begin{tabular}{|c|c|c|c|c|c|c|c|c|}
\hline \multirow[t]{2}{*}{ Dimension } & \multicolumn{2}{|c|}{ Levene's Test } & \multirow[t]{2}{*}{ Gender } & \multirow[t]{2}{*}{ Mean } & \multirow{2}{*}{$\begin{array}{l}\text { Standard } \\
\text { Deviation }\end{array}$} & \multirow[t]{2}{*}{ P-value } & \multirow[t]{2}{*}{$t$} & \multirow[t]{2}{*}{ Cohen D } \\
\hline & $F$ & Sig & & & & & & \\
\hline \multirow{2}{*}{$\begin{array}{l}\text { Environmental issues and } \\
\text { problems }\end{array}$} & \multirow[t]{2}{*}{3.141} & \multirow[t]{2}{*}{.078} & Male & 3.45 & .780 & \multirow[t]{2}{*}{.017} & \multirow[t]{2}{*}{-2.402} & \multirow[t]{2}{*}{0.35} \\
\hline & & & Female & 3.19 & .725 & & & \\
\hline \multirow[t]{2}{*}{ Land degradation } & \multirow[t]{2}{*}{2.779} & \multirow[t]{2}{*}{.097} & Male & 3.49 & .725 & \multirow[t]{2}{*}{.004} & \multirow[t]{2}{*}{-2.908} & \multirow[t]{2}{*}{0.41} \\
\hline & & & Female & 3.20 & .674 & & & \\
\hline \multirow[t]{2}{*}{ Urban Sprawl } & \multirow[t]{2}{*}{3.583} & \multirow[t]{2}{*}{.060} & Male & 3.45 & .806 & \multirow[t]{2}{*}{.030} & \multirow[t]{2}{*}{-2.191} & \multirow[t]{2}{*}{0.31} \\
\hline & & & Female & 3.21 & .720 & & & \\
\hline \multirow[t]{2}{*}{ Water Pollution } & \multirow[t]{2}{*}{1.513} & \multirow[t]{2}{*}{.220} & Male & 3.06 & 1.084 & \multirow[t]{2}{*}{.025} & \multirow[t]{2}{*}{-2.265} & \multirow[t]{2}{*}{0.32} \\
\hline & & & Female & 2.73 & .988 & & & \\
\hline \multirow[t]{2}{*}{ Air Pollution } & \multirow[t]{2}{*}{1.011} & .316 & Male & 3.13 & 1.084 & .001 & -3.595 & 0.37 \\
\hline & & & Female & 2.73 & 1.076 & & & \\
\hline Biodiversity & .951 & .331 & Male & 3.19 & 1.059 & .001 & -4.269 & 0.61 \\
\hline & & & Female & 2.54 & 1.088 & & & \\
\hline Sustainability & 3.488 & .063 & Male & 3.47 & .739 & .009 & -2.644 & 0.38 \\
\hline & & & Female & 3.20 & .688 & & & \\
\hline Watershed management & .265 & .607 & Male & 3.20 & 1.062 & .001 & -4.326 & 0.61 \\
\hline & & & Female & 2.55 & 1.060 & & & \\
\hline Conservation of natural resources & .547 & .461 & Male & 3.15 & 1.015 & .003 & -2.959 & 0.42 \\
\hline & & & Female & 2.73 & .968 & & & \\
\hline Wetland & 1.50 & .699 & Male & 3.17 & 1.033 & .001 & -3.622 & 0.52 \\
\hline & & & Female & 2.63 & 1.043 & & & \\
\hline
\end{tabular}


Table 5: General Environmental Knowledge of Household heads stratified by demographic characteristics

\begin{tabular}{|c|c|c|c|}
\hline Parameter & $\begin{array}{c}\text { Improvement } \\
\text { Required (Poor) }\end{array}$ & Acceptable (Good) & $\begin{array}{c}\text { High Quality } \\
\text { (Excellent) }\end{array}$ \\
\hline Total Respondents & $89(23.67)$ & $120(31.91)$ & $167(44.41)$ \\
\hline Gender: Male & $63(20.19)$ & $98(31.41)$ & $151(48.40)$ \\
\hline Female & $26(40.63)$ & $22(34.38)$ & $16(25.00)$ \\
\hline Age: $18-40$ & $10(16.13)$ & $17(27.42)$ & $35(56.45)$ \\
\hline $41-60$ & $39(24.68)$ & $47(29.75)$ & $72(45.57)$ \\
\hline $61-80$ & $36(25.00)$ & $52(36.11)$ & $56(38.89)$ \\
\hline $81-100$ & $4(33.33)$ & $4(33.33)$ & $4(33.33)$ \\
\hline Educational level: None & $8(14.55)$ & $13(23.64)$ & $34(61.82)$ \\
\hline Primary & $37(22.70)$ & $49(30.06)$ & $77(47.24)$ \\
\hline Junior High & $23(27.06)$ & $41(48.24)$ & $21(24.71)$ \\
\hline Senior High & $17(27.42)$ & $12(19.35)$ & $33(53.23)$ \\
\hline Tertiary & $4(36.36)$ & $5(45.45)$ & $2(18.18)$ \\
\hline Marital Status: Single & $6(18.75)$ & $12(37.50)$ & $14(43.75)$ \\
\hline Monogamously Married & $56(20.74)$ & $88(32.59)$ & $126(46.67)$ \\
\hline Polygamously Married & $2(14.29)$ & $6(42.86)$ & $6(42.86)$ \\
\hline Widowed & $19(44.19)$ & $10(23.26)$ & $14(32.56)$ \\
\hline Separated/Divorced & $6(35.29)$ & $4(23.53)$ & $7(41.18)$ \\
\hline \multicolumn{4}{|l|}{ Religious Denomination } \\
\hline No Religion & $0(0.00)$ & $4(33.33)$ & $8(66.67)$ \\
\hline Orthodox & $23(23.47)$ & $29(29.59)$ & $46(46.94)$ \\
\hline Protestant & $15(34.09)$ & $12(27.27)$ & $17(38.64)$ \\
\hline Pentecostal & $26(25.74)$ & $33(32.67)$ & $42(41.58)$ \\
\hline Charismatics & $16(22.54)$ & $24(33.80)$ & $31(43.66)$ \\
\hline Other Christians & $4(14.81)$ & $7(25.93)$ & $16(59.26)$ \\
\hline Islam & $0(0.00)$ & $9(69.23)$ & $4(30.77)$ \\
\hline Traditionalist & $1(25.00)$ & $2(50.00)$ & $1(25.00)$ \\
\hline Others & $3(60.00)$ & $0(0.00)$ & $2(40.00)$ \\
\hline Ethnicity: Akan & $62(25.10)$ & $80(32.39)$ & $105(42.51)$ \\
\hline Ewe & $12(23.53)$ & $18(35.29)$ & $21(41.18)$ \\
\hline Ga-Dangme & $12(22.64)$ & $11(20.75)$ & $30(56.60)$ \\
\hline Dagbani & $0(0.00)$ & $1(100.00)$ & $0(0.00)$ \\
\hline Frafra/Grusi & $1(20.00)$ & $3(60.00)$ & $1(20.00)$ \\
\hline Nzema & $0(0.00)$ & $1(100.00)$ & $0(0.00)$ \\
\hline Wali/Dgari & $0(0.00)$ & $3(42.86)$ & $4(57.14)$ \\
\hline Others & $2(18.18)$ & $3(27.27)$ & $6(54.55)$ \\
\hline
\end{tabular}

Source: Author's own from field-work. Data is presented as a figure with the corresponding percentage in parenthesis 
Table 6: General Environmental Knowledge of Senior High School Students stratified by demographic characteristics

\begin{tabular}{|c|c|c|c|}
\hline Parameter & $\begin{array}{c}\text { Improvement } \\
\text { Required (Poor) }\end{array}$ & $\begin{array}{l}\text { Acceptable } \\
\text { (Good) }\end{array}$ & $\begin{array}{c}\text { High Quality } \\
\text { (Excellent) }\end{array}$ \\
\hline Total respondents & $41(20.50)$ & $53(26.50)$ & $106(53.00)$ \\
\hline Gender: Male & $13(13.54)$ & $25(26.04)$ & $58(60.42)$ \\
\hline Female & $28(26.92)$ & $28(26.92)$ & $48(46.15)$ \\
\hline $14-15$ & $3(20.00)$ & $4(26.67)$ & $8(53.33)$ \\
\hline $16-17$ & $28(21.05)$ & $35(26.32)$ & $70(52.63)$ \\
\hline $18-20$ & $10(19.23)$ & $14(26.92)$ & $28(53.85)$ \\
\hline \multicolumn{4}{|l|}{ Program of study } \\
\hline Generals Arts & $10(29.41)$ & $7(20.59)$ & $17(50.00)$ \\
\hline Business Studies & $6(17.65)$ & $9(26.47)$ & $19(55.88)$ \\
\hline General Science & $5(14.71)$ & $9(26.47)$ & $20(58.82)$ \\
\hline Home Economics & $5(15.15)$ & $9(27.27)$ & $19(57.58)$ \\
\hline Visual Arts & $11(32.35)$ & $11(32.35)$ & $12(35.29)$ \\
\hline Agricultural Science & $3(20.00)$ & $3(20.00)$ & $9(60.00)$ \\
\hline Technical & $1(6.25)$ & $5(31.25)$ & $10(62.50)$ \\
\hline \multicolumn{4}{|l|}{ Religious denomination } \\
\hline Orthodox & $25(24.27)$ & $23(22.33)$ & $55(53.40)$ \\
\hline Pentecostals & $10(22.22)$ & $13(28.89)$ & $22(48.89)$ \\
\hline Charismatics & $0(0.00)$ & $5(31.25)$ & $11(68.75)$ \\
\hline Other Christians & $3(15.79)$ & $8(42.11)$ & $8(42.11)$ \\
\hline Islam & $3(21.43)$ & $2(14.29)$ & $9(64.29)$ \\
\hline Traditionalist & $0(0.00)$ & $0(0.00)$ & $1(100.00)$ \\
\hline Others & $0(0.00)$ & $2(100.00)$ & $0(0.00)$ \\
\hline \multicolumn{4}{|l|}{ Father's education level } \\
\hline None & $2(28.57)$ & $2(28.57)$ & $3(42.86)$ \\
\hline Primary & $2(16.67)$ & $4(33.33)$ & $6(50.00)$ \\
\hline JHS & $12(21.43)$ & $17(30.36)$ & $28(50.00)$ \\
\hline SHS & $15(21.74)$ & $16(23.19)$ & $38(55.07)$ \\
\hline Tertiary & $9(17.31)$ & $13(25.00)$ & $29(55.77)$ \\
\hline Others & $1(25.00)$ & $1(25.00)$ & $2(50.00)$ \\
\hline \multicolumn{4}{|l|}{ Mother's education level } \\
\hline None & $4(26.67)$ & $6(40.00)$ & $5(33.33)$ \\
\hline Primary & $2(10.53)$ & $5(26.32)$ & $12(63.16)$ \\
\hline JHS & $14(21.54)$ & $14(21.54)$ & $37(56.92)$ \\
\hline SHS & $12(16.67)$ & $22(30.56)$ & $39(54.17)$ \\
\hline Tertiary & $9(33.33)$ & $5(18.52)$ & $12(44.44)$ \\
\hline Others & $0(0.00)$ & $1(50.00)$ & $1(50.00)$ \\
\hline
\end{tabular}

Source: Author's own from field-work. Data is presented as a figure with the corresponding percentage in parenthesis 


\subsection{Linear Probability Model estimates}

Tables 7 and 8 shows the results from the Ordinary Least Square (OLS) or Linear Probability Model (LPM) estimates of household heads (farmers) and SHS students, respectively. Among the household heads group, age, level of formal education, years of farming experience, marital status, religious denomination, ethnicity, and income are unrelated to their perceived environmental knowledge score. This means that age, level of formal education, years of farming experience, marital status, religious denomination, ethnicity, and income are not important factors in predicting the household head's perceived environmental knowledge score. However, the coefficients of "male" are statistically significant at 5\% level of significance for the household heads model specification. The results indicate that being a male increases the probability of having perceived environmental knowledge by 30.8 percentage points, controlling other demographic characteristics. The coefficient of age is positive but not statistically significant, this is due of the small sample size. Education among the household heads was also positive but not significant due to the large number of farmers who have either no education or a lower level of education.

Table 7: Linear Probability Model (LPM) estimates of perceived environmental knowledge of household heads/farmers

\begin{tabular}{lc}
\hline Variables & Perceived Environmental Knowledge Score \\
\hline Age & $\mathbf{0 . 0 0 0 1 6}$ \\
& $(-0.0067)$ \\
Male & $\mathbf{0 . 3 0 8} * *$ \\
& $(-0.138)$ \\
Education & $\mathbf{0 . 0 5 9 1}$ \\
& $(-0.0454)$ \\
Years of farming experience & 0.00085 \\
& $(-0.0072)$ \\
Marital Status & 0.108 \\
Religious Denomination & $-0.101)$ \\
& 0.00321 \\
Ethnicity & $(-0.0255)$ \\
& -0.0277 \\
Municipality & $-0.0258)$ \\
& 0.0703 \\
Income & $(-0.0975)$ \\
Constant & -0.0221 \\
& $(-0.0937)$ \\
Observations & $0.691 * *$ \\
R-squared & $(-0.281)$ \\
\hline Robust standard errors in parentheses & 376 \\
$* * *$ p $<0.01, * * p<0.05, * 0.1$ & 0.054 \\
\hline Source: Author's own from field-work (July/August 2019) & \\
& \\
&
\end{tabular}

Among the SHS group age, age square, region of origin, the program of study, religious denomination, and parents' educational level are unrelated to their perceived environmental knowledge score. This suggests that age, region of origin, program of study, religious denomination, and parents' educational level are not considered as influential factors in predicting the SHS students perceived environmental knowledge score. However, the coefficients "female" and "SHS grade" are statistically significant at $5 \%$ and $1 \%$ level of significance for SHS group model specification, respectively. The results indicate that being a female decreases the probability of having perceived environmental knowledge by 26 percentage points, controlling other demographic characteristics. Whiles being enrolled in an SHS increases the probability of having perceived environmental knowledge by 30.8 percentage points, controlling other demographic characteristics. The coefficient of age is positive but not statistically significant, this is due of the small sample size. 
Table 8: Linear Probability Model (LPM) estimates of perceived environmental knowledge of SHS students

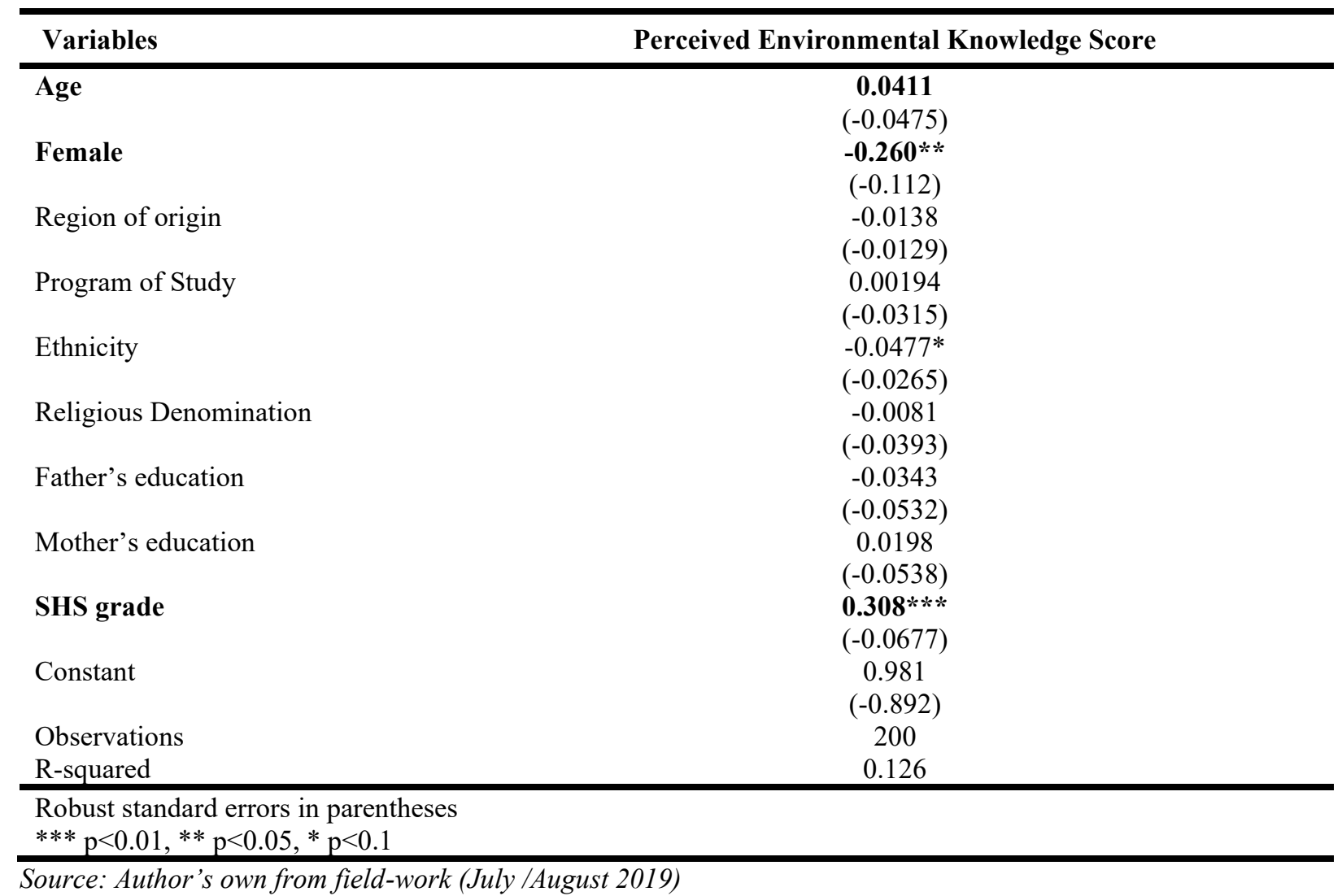

\subsection{Laws and regulations on environmental issues}

In the questionnaire, both household heads and SHS students were asked on how they think about the state of laws and regulations preventing a set of environmental issues/problems with option as follow: 1. have gone too far, 2. not far enough, 3. have struck about the right balance 4. No idea. Tables 9 and 10 present their views on the strength of the existing laws and regulations to deal with the environmental crisis. Overall, findings indicates that respondents are of the view that the current laws and regulations preventing and protecting the existing environmental problems and challenges are not enough to deal with the mess created.

The study found that over $60 \%$ of the farmers opines that the current laws and regulations are lack of implementation and enforcement to deal with the environmental challenges. Their opinion may be due to their experience with the tiling of farmlands. The SHS students were not different in their opinion with regards to the weak laws and regulations preventing/protecting the environment. Through their direct observations and what they have learned from their curricula, they are convinced that the laws and regulations have not gone far enough to protect the environment.

Table 9: Household heads' views on laws and regulation preventing/protecting environmental crisis

\begin{tabular}{lcccc}
\hline Environmental issues & $\begin{array}{c}\text { Have gone too } \\
\text { far }\end{array}$ & $\begin{array}{c}\text { Not far } \\
\text { enough }\end{array}$ & $\begin{array}{c}\text { Have struck about the } \\
\text { right balance }\end{array}$ & No idea \\
\hline Land degradation & $97(25.80)$ & $241(64.10)$ & $20(5.32)$ & $18(4.79)$ \\
Water pollution & $95(25.27)$ & $249(66.22)$ & $21(5.59)$ & $11(2.93)$ \\
Air pollution & $88(23.40)$ & $247(65.69)$ & $24(6.38)$ & $17(4.52)$ \\
Conservation. of natural & $101(26.86)$ & $243(64.63)$ & $17(4.52)$ & $15(3.99)$ \\
resources & $59(15.69)$ & $251(66.76)$ & $25(6.65)$ & $41(10.90)$ \\
Wetlands & $75(19.95)$ & $220(58.51)$ & $33(8.78)$ & $48(12.77)$ \\
\hline Urban Sprawl & & & & \\
\hline
\end{tabular}

Source: Author's own from field-work (July /August 2019).

Data is presented as a figure with the corresponding percentage in parenthesis 
Table 10: SHS student views on Laws and regulation preventing/protecting environmental crisis

\begin{tabular}{lcccc}
\hline Environmental issues & $\begin{array}{c}\text { Have gone } \\
\text { too far }\end{array}$ & $\begin{array}{c}\text { Not far } \\
\text { enough }\end{array}$ & $\begin{array}{c}\text { Have struck about } \\
\text { the right balance }\end{array}$ & No idea \\
\hline Land degradation & $25(12.50)$ & $141(70.50)$ & $32(16.00)$ & $2(1.00)$ \\
Water pollution & $36(18.00)$ & $120(60.00)$ & $42(21.00)$ & $2(1.00)$ \\
Air pollution & $38(19.00)$ & $109(54.50)$ & $49(24.50)$ & $4(2.00)$ \\
Conservation. of natural & & & & \\
resources & $35(17.50)$ & $107(53.50)$ & $44(22.00)$ & $14(7.00)$ \\
Wetlands & $12(6.00)$ & $60(30.00)$ & $46(23.00)$ & $82(41.00)$ \\
Urban Sprawl & $6(3.00)$ & $73(36.50)$ & $35(17.50)$ & $86(43.00)$ \\
\hline
\end{tabular}

Source: Author's own from field-work (July /August 2019).

Data is presented as a figure with the corresponding percentage in parenthesis

\subsection{Environmental responsibility}

Using a five-point Likert scale with $1=$ strongly agree, $2=$ agree, $3=$ neutral, $4=$ disagree, and 5= strongly disagree, the 376 farmers and the 200 students were asked as to identify who they think should take up the responsibility of finding solutions to the environmental problems in the Municipality/Ghana. Tables 11 and 12 summarizes respondents' choices. $64.10 \%$ of farmers (household heads) strongly agree that the greater responsibility should be placed on the head of the central government and the municipal authorities, followed by individual citizens with $50.27 \%$. The farmers put the major environmental responsibility on the government rather than the individual citizens, business and industry, and agriculture and forestry that created the environmental mess.

In another twist, $65.5 \%$ of the students think the individual citizens should rather take the leading role in addressing the environmental challenges. They placed the environmental responsibility on government/municipal authority after the individuals followed by agriculture and forestry. Their choice indicates that they are more ready to correct the mess created than to rely on the central and municipal governments for solution. Moreover, given $64.5 \%$ to the central/municipal government and $65.5 \%$ to the individuals reveals their believe in stakeholder approach to environmental sustainability.

Table 11: Household heads sense of Environmental responsibility

\begin{tabular}{lccccc}
\hline $\begin{array}{l}\text { Environmental } \\
\text { responsibility }\end{array}$ & $\begin{array}{c}\text { Strongly } \\
\text { agree }\end{array}$ & Agree & Neutral & Disagree & $\begin{array}{c}\text { Strongly } \\
\text { disagree }\end{array}$ \\
\hline Business and Industry & $112(29.79)$ & $139(36.97)$ & $8(2.13)$ & $64(17.02)$ & $53(14.10)$ \\
Government/Mun. Ass. & $241(64.10)$ & $109(28.99)$ & $0(0.00)$ & $21(5.59)$ & $5(1.33)$ \\
Individual citizens & $189(50.27)$ & $153(40.69)$ & $0(0.00)$ & $24(6.38)$ & $10(2.66)$ \\
Agriculture and forestry & $172(45.74)$ & $155(41.22)$ & $4(1.06)$ & $34(9.04)$ & $11(2.93)$ \\
\hline
\end{tabular}

Source: Author's own from field-work (July /August 2019).

Data is presented as a figure with the corresponding percentage in parenthesis

Table 12: SHS students' sense of Environmental responsibility

\begin{tabular}{lccccc}
\hline $\begin{array}{l}\text { Environmental } \\
\text { responsibility }\end{array}$ & $\begin{array}{c}\text { Strongly } \\
\text { agree }\end{array}$ & Agree & Neutral & Disagree & $\begin{array}{c}\text { Strongly } \\
\text { disagree }\end{array}$ \\
\hline Business and Industry & $60(30.00)$ & $90(45.00)$ & $1(0.50)$ & $35(17.50)$ & $14(7.00)$ \\
Government/ Mun. Ass. & $129(64.50)$ & $60(30.00)$ & $2(1.00)$ & $8(4.00)$ & $1(0.50)$ \\
Individual citizens & $131(65.50)$ & $59(29.50)$ & $1(0.50)$ & $6(3.00)$ & $3(1.50)$ \\
Agriculture and forestry & $70(35.00)$ & $93(46.50)$ & $8(4.00)$ & $21(10.50)$ & $8(4.00)$ \\
\hline
\end{tabular}

Source: Author's own from field-work (July /August 2019).

Data is presented as a figure with the corresponding percentage in parenthesis 


\subsection{Sources of environmental information}

Table 13 shows a summary of the sources of environmental information provided by the two groups surveyed. There were variations between the two groups when they were asked to choose their sources of environmental education. They were to choose from education, newspaper, ration/TV, internet and other sources. Among the farmer-based group, radio/TV came out on top with $57.98 \%$, followed by education with $32.71 \%$ and newspaper with $8.51 \%$. The internet as a source of environmental information was chosen by only $0.27 \%$. The results show that the older generation is glued to the traditional sources of information. The choice of the environmental information sources of the SHS students was evident as $64 \%$ choose education as their primary source, followed by radio/TV with $22 \%$ and internet with $11 \%$. Only $1 \%$ of SHS students choose newspapers as their source of environmental information.

Table 13: Sources of Environmental information

\begin{tabular}{ccc}
\hline Sources & $\begin{array}{c}\text { Household heads } \\
(\%)\end{array}$ & $\begin{array}{c}\text { SHS students } \\
(\%)\end{array}$ \\
\hline Education & 32.71 & 64 \\
Newspaper & 8.51 & 1 \\
Radio/TV & 57.98 & 22 \\
Internet & 0.27 & 11 \\
Others & 0.53 & 2 \\
\hline
\end{tabular}

Source: Author's own from field-work. (July /August 2019)

\subsection{Steps to protect the environment}

To wave into whether the level of environmental awareness translates into a pro-environmental behavior, respondents were asked to choose among the available options with regards to what they do to protect the environment. They were to indicate whether they plant trees or dispose of solid waste properly or dispose of liquid waste properly or do not use fossil fuel or educate others on pro-environmental behaviors. Tables 14 presents a summary of the steps taken by respondents to protects the environment. It is reasonable and understandable to see $43.35 \%$ of farmers indicated that they plant trees to save and protect the environment as their daily work is related to farming. Proper disposal of solid and liquid wastes was chosen by $31.38 \%$ and $10.11 \%$ of the farmer-based respondents.

To wave into whether the level of environmental awareness translates into a pro-environmental behavior, respondents were asked to choose among the available options as to what they do to protect the environment. They were to indicate whether they plant trees or dispose of solid waste properly or dispose of liquid waste properly or do not use fossil fuel or educate others on pro-environmental behaviors. Table 14 presents a summary of the steps taken by respondents to protects the environment. It is reasonable and understandable to see $43.35 \%$ of farmers indicated that they plant trees to save and protect the environment as their daily work is related to farming. Proper disposal of solid and liquid wastes was chosen by $31.38 \%$ and $10.11 \%$ of the farmer-based respondents.

Table 14:Steps to protects the environment by household heads/farmers' and SHS students'

\begin{tabular}{lccccc}
\hline & $\begin{array}{c}\text { Plant } \\
\text { trees }\end{array}$ & $\begin{array}{c}\text { Dispose solid } \\
\text { waste properly }\end{array}$ & $\begin{array}{c}\text { Dispose liquid } \\
\text { waste properly }\end{array}$ & $\begin{array}{c}\text { No use of } \\
\text { fossil fuel }\end{array}$ & $\begin{array}{c}\text { Educate } \\
\text { others }\end{array}$ \\
\hline Household heads & $43.35 \%$ & $31.38 \%$ & $10.11 \%$ & $0.80 \%$ & $14.36 \%$ \\
SHS students & $17 \%$ & $27 \%$ & $1.5 \%$ & $2.5 \%$ & $53 \%$ \\
\hline
\end{tabular}

Source: Author's own from field-work (July /August 2019). 


\subsection{Rank of the most important environmental issues}

The respondents were also asked to rank thirteen (13) environmental issues and problems to indicate their concern for the environment and solution to protect the environment. Tables 15 and 16 presents how both household heads and SHS students ranked the most pressing environmental issue in modern times. It was found that over $32 \%$ ranked water pollution as the topmost environmental concern by the two groups surveyed. Among the household heads, deforestation, air pollution, and soil erosion were the other top priorities as far as their work and daily lives are concern.

However, sustainability, biodiversity, climate change, and residue of farming chemicals were the lowest-ranked environmental concerns by $1.3 \%$ or less of the household heads respondents. An illustration of consuming available resources to meet the needs of today without considering that of the necessities of tomorrow. Conservation of natural resources, air pollution, and deforestation were of utmost concern to the students sampled. Moreover, climate change, sustainability, chemical waste, noise pollution, and biodiversity were the environmental concerns that were ranked by $1.5 \%$ or less of the respondents.

Table 15: Rank of farmer's most important environmental issues

\begin{tabular}{llc}
\hline Rank & \multicolumn{1}{c}{$\begin{array}{c}\text { Most important } \\
\text { environmental issue }\end{array}$} & Percentage \\
\hline 1 & Water pollution & 32.98 \\
2 & Deforestation & 20.21 \\
3 & Air pollution & 12.50 \\
4 & Soil erosion & 10.11 \\
5 & Solid and liquid wastes & 6.91 \\
6 & Wetlands & 5.85 \\
7 & Chemical waste & 5.59 \\
8 & Conservation of natural & 2.13 \\
9 & resources & 1.60 \\
10 & Noise pollution & 1.33 \\
11 & Sustainability & 0.53 \\
12 & Biodiversity & 0.27 \\
& Climate change & 0.00 \\
\hline
\end{tabular}

Source: Author's own from fieldwork. (July /August 2019)
Table 16: Rank of SHS most important environmental issues

\begin{tabular}{|c|c|c|}
\hline Rank & $\begin{array}{c}\text { Most important } \\
\text { environmental issue }\end{array}$ & Percentage \\
\hline 1 & Water pollution & 35.00 \\
\hline 2 & $\begin{array}{l}\text { Conservation of natural } \\
\text { resources }\end{array}$ & 18.00 \\
\hline 3 & Air pollution & 14.50 \\
\hline 4 & Deforestation & 11.50 \\
\hline 5 & Solid and liquid wastes & 8.00 \\
\hline 6 & Soil erosion & 3.50 \\
\hline 7 & Wetlands & 3.00 \\
\hline 8 & Residue of farming chemicals & 3.00 \\
\hline 9 & Climate change & 1.50 \\
\hline 10 & Sustainability & 1.00 \\
\hline 11 & Chemical waste & 0.50 \\
\hline 12 & Noise pollution & 0.50 \\
\hline 13 & Biodiversity & 0.00 \\
\hline
\end{tabular}

The results of the question relating to Ghana's environmental condition in the next five years is given in table 17 , $81.91 \%$ and $94 \%$ of farmers and students respectively opine that Ghana's environment in the next five years is likely to worsen compared to $18.09 \%$ and $6 \%$ of household heads (farmers) and students, respectively, who think otherwise.

In assessing the readiness of respondents to avail themselves to be trained and be equipped to face the environmental challenges, table 18 presents responses from respondents. $81.65 \%$ and $98.5 \%$ of farmers and students indicated that they would avail themselves to be well equipped to attend to the environment. 
Table 17: Opinion on Ghana's environmental condition in the next 5 years.

\begin{tabular}{lcc}
\hline Condition & $\begin{array}{c}\text { Household } \\
\text { heads }\end{array}$ & $\begin{array}{c}\text { SHS } \\
\text { students }\end{array}$ \\
\hline Better & $18.09 \%$ & $6.00 \%$ \\
Worse & $81.91 \%$ & $94.00 \%$ \\
\hline Source: Author's & own from field-work. (July \\
/August 2019) & \multicolumn{3}{l}{}
\end{tabular}

Table 18:Availability to equip oneself to save the ailing environment.

\begin{tabular}{lcc}
\hline $\begin{array}{l}\text { Availability } \\
\text { for training }\end{array}$ & $\begin{array}{c}\text { Household } \\
\text { heads }\end{array}$ & $\begin{array}{c}\text { SHS } \\
\text { students }\end{array}$ \\
\hline Yes & $81.65 \%$ & $98.50 \%$ \\
No & $18.35 \%$ & $1.50 \%$ \\
\hline Source: Author's own from field-work. (July \\
/August 2019)
\end{tabular}

\section{Discussions}

The small number of farmers with tertiary education suggests that the higher educational attainment of a farmer the less he/she depends on farming activities as they may have other formal jobs as a source of income. This is a reflection of a weeding culture that exists in the Ghanaian school system where weeding is used as a form of punishment in schools. This has created the notion that the higher one climbs the educational ladder, the higher the possibility of substituting farming for a more formal and higher income generating job.

The results of the comparative analysis between the older and younger generation from a different survey are reasonable. It makes sense that the younger generation achieved a higher level of knowledge than the older due to their access to senior high school (SHS) education and the easy access to modern resources of information such as the internet, magazines, and social media platforms. The development of greater interest on the part of the youth coupled with the modern sources of knowledge and the access to free SHS education in Ghana have influenced the level of knowledge of the younger generation but this was not the case a few decades ago. Also, the higher level of environmental consciousness was influenced by both the old and new curricula developed by the Ghana Education Services contains environmental information/education right from the lower primary to the tertiary level.

Dedicating a subject dubbed "Environmental Studies" in the primary schools in Ghana has had a significant influence on shaping their awareness of environmental issues. Moreover, the redesigning subjects called "Our World Our People" and "Citizenship Education" for the lower and upper primary and social studies for the JHS and SHS levels would further broaden their knowledge in environmental issues. The inclusion of environmental education in the most recent education curriculum and environmental reporting segment on TV/radio stations across the country has made the younger generation more attentive to the possible threats that await them as they prepare themselves to inherit the already deplorable environment which may threaten their survival. Regular advertisements on televisions and radio stations also have made them aware of their immediate surroundings.

In targeting the younger generation to improve their environmental awareness, newspapers should not be the targeted medium as most students hardly read newspapers compared to other sources of environmental information. The most important medium to spark environmentalism among the younger generation is through formal education; it is more effective when the basic and secondary education is free. This permits all children of school-going age to be enrolled and have access to such education.

The results from the survey indicate that males in the farmer and SHS students group have more awareness/consciousness about environmental issues than their female counterparts. It is expected that females become more knowledgeable than males due to their active engagement in household oriented pro-environmental activities. Moreover, females' pattern of socialization is expected to influence a higher level of knowledge in the environment, but this survey proves otherwise. The socialization orientation of males coupled with their desire to dominate the environment could be a reason for higher awareness. Also, females are not likely to take leading roles or to have a higher interest in pro-environmental public behaviors but their male counterparts usually lead to such endeavors. Results may vary depending on the country and whether the study seeks to know the awareness level from either the private or the public awareness perspective.

Interestingly, other studies found pollution to be the number one environmental concern, and the most commonly talked about (Heaton \& Burns, 2014; Willuweit, 2009). The availability of the younger generation to equip themselves to face what awaits them in the future is enough to bring environmental education to another level. 
Having accepted to be trained through education signifies that improved access to education with environmental content is the surest way to deal with future uncertainties to ensure sustainable development.

In achieving sustainable development, it has become obvious that the younger generation has the motivation, improved environmental awareness, and is available to gain more knowledge and skills to become and raise an environmental generation. These meet the requirements of the three most important elements of the Environmental Generation Theory. This theory has the potential of improving environmental well-being of the next generation as their awareness of the consequences of their unfriendly environmental behavior would jeopardize sustainability.

The independent sample t-test result shows that there were significant differences between mand and female in their perceived environmental knowledge score as males were found to have higher environmental knowledge. The multiple linear regression analysis results show that educational level and gender factors contributed significantly to their perceived environmental knowledge by both generations. However, age of both generations did not contribute significantly to perceived environmental knowledge but the coefficient is positive in both cases.

The cumulative percentage performance analysis revealed that SHS students scored higher environmental knowledge (79.50\%) than the older generation (76.32\%). Even among the household heads, scores show that the younger age group of 18-40 demonstrated a high level of knowledge with $83.87 \%$ (sum of good and excellent scores) compared to $75.32 \%$ of the older $41-60$-year group, much older $75 \%$ of the $61-80$-year group and $66.66 \%$ of the oldest group of the above 80 years. Using the cumulative percentage performance, age plays an important role.

Other results indicate that $65.5 \%$ of the younger generation would like to take the leading role in addressing the environmental challenges as they place environmental responsibility on the shoulders of the individual citizens rather than the local/municipal authority. On the other hand, $64.10 \%$ of farmers (household heads) strongly agree that it is the responsibility of the central government and the municipal authorities. This suggests that the younger generation is more motivated and exposed to the reality of environmental issues and problems.

Results from the Linear Probability Model indicate that being a male and a farmer residing at Abuakwa North Municipality increases the probability of household head (farmers) having a higher perceived environmental knowledge score controlling other demographic characteristics. Also, the coefficients of "female" and "SHS grade" are statistically significant at 5\% and $1 \%$ level of significance for SHS group model specification, respectively. The results indicate that being a female decrease the probability of having perceived environmental knowledge controlling other demographic characteristics. Whiles being enrolled in an SHS increases the probability of having perceived environmental knowledge controlling other demographic characteristics.

But despites these, if the land tenure system remains as it has been, then, there is the likelihood that these efforts would be in vain. The old land tenure system is a major factor contributing to the poor harvest and land degradation, hence, preventing a green revolution take-off.

Results from the assessment of the perceived knowledge in environmental issues and problems demonstrated a higher environmental awareness among the SHS students than the household head farmers who under normal circumstances were expected be more conscious and show concern for the environment due to their nature of work and experience but everything points to the fact that they place emotional glory over the acquisition of knowledge. Even among the household heads, scores show that the younger age group revealed a higher level of knowledge than their colleague older farmers.

Moreover, the younger generation appeared to be more responsible and are ready to take up the mantle of giving a new face to the environment by opting to place the environmental responsibility on their shoulders rather than putting on the central government, municipal and local authorities. The younger generation is more ready to educate others on environmental issues as demonstrated when asked what they do to protect the environment. Furthermore, over $98 \%$ of the students indicated their readiness to acquire the needed skills and knowledge to change the negative environmental outlook to a positive one. Results from the linear probability model shows that being enrolled in a SHS increases the probability of having perceived environmental knowledge controlling other demographic characteristics.

In response to the results above and in the spirit of achieving increased environmental well-being, it is obvious that the younger generation has the motivation, improved environmental awareness, and is available to gain more knowledge and skills to become and raise an environmental generation. These meet the requirements of the three 
most important elements of the Environmental Generation Framework. A youthful generation that is conscious of their environment and the consequences of human activities towards the environment would prioritize the acquisition and gathering of knowledge and skills to save the environment from deteriorating. The introduction of the Environmental Generation Framework is apt to spark environmentalism among the younger generation or to raise an environmental generation.

\section{Conclusions}

One of the possible ways of mitigating and adapting to the effects of climate change is through environmental education. The current and next generations have been the target but it is still unclear whether the main focus should either be on the current or the next generation.

Among the household heads group, age, level of formal education, years of farming experience, marital status, religious denomination, ethnicity, and income are unrelated to environmental knowledge. However, the coefficients of "male" are statistically significant at a 5\% level of significance for the household heads model specification, respectively. The results indicate that being a male increases the probability of having perceived environmental knowledge by 30.8 percentage points, controlling other demographic characteristics.

Among the SHS group age, the region of origin, the program of study, religious denomination, and parents' educational level are unrelated to perceived environmental knowledge. However, the coefficients "female" and "SHS grade" are statistically significant at a 5\% and 1\% level of significance for SHS group model specification, respectively. The results indicate that being a female decrease the probability of having perceived environmental knowledge by 26 percentage points, controlling other demographic characteristics. Whiles being enrolled in an SHS increases the probability of having perceived environmental knowledge by 30.8 percentage points, controlling other demographic characteristics.

The coefficient of age in both cases is positive but not statistically significant. A possible explanation for age not been significant could be due to the small sample size. One of the most important variables "education" was not significant among the household heads' group due to the low level of education among farmers in the rural communities. However, education among the SHS group was significant suggesting that the younger generation in either the first, second, or third year of SHS studies influences their perceived environmental knowledge. The new free SHS policy in Ghana is likely to facilitate and improve an increase of environmental knowledge of the future generation hence the anticipation of achieving environmental sustainability.

At this point, it is obvious that the younger generation has the motivation, improved environmental awareness, the basic environmental knowledge and is available to gain more knowledge and skills to become and raise an environmental generation. Therefore, we can conclude that the emphasizes should be on the younger generation but not forgetting the current generation.

\section{REFERENCES}

Adu, I. K., Tetteh, J. D., Puthenkalam, J. J., \& Antwi, K. E. (2020). Intensity Analysis to Link Changes in LandUse Pattern in the Abuakwa North and South Municipalities, Ghana, from 1986 to 2017. International Journal of Geological and Environmental Engineering, 14(8), 225-242.

Agyeman, B. A. S., Asuming-Brempong, S., \& Onumah, E. E. (2014). Determinants of income diversification of farm households in the western region of Ghana.

Ahmad, J., Noor, S. M., \& Ismail, N. (2015). Investigating students' environmental knowledge, attitude, practice and communication. Asian Social Science, 11(16), 284.

Archibald, S., Staver, A. C., \& Levin, S. A. (2012). Evolution of human-driven fire regimes in Africa. Proceedings of the National Academy of Sciences, 109(3), 847-852.

Arneth, A., Barbosa, H., Benton, T., Calvin, K., Calvo, E., Connors, S., . . van Diemen, R. (2019). IPCC special report on climate change, desertification, land degradation, sustainable land management, food security, and greenhouse gas fluxes in terrestrial ecosystems. In: Technical report, Intergovernmental Panel on Climate Change.

Barbier, E. B., \& Hochard, J. P. (2018a). The impacts of climate change on the poor in disadvantaged regions. Review of Environmental Economics and Policy, 12(1), 26-47.

Barbier, E. B., \& Hochard, J. P. (2018b). Land degradation and poverty. Nature Sustainability, 1(11), 623-631. 
Behnassi, M., Shahid, S. A., \& D'Silva, J. (2011). Sustainable agricultural development: recent approaches in resources management and environmentally-balanced production enhancement: Springer Science \& Business Media.

Boakye-Danquah, J., Antwi, E. K., Saito, O., Abekoe, M. K., \& Takeuchi, K. (2014). Impact of farm management practices and agricultural land use on soil organic carbon storage potential in the savannah ecological zone of Northern Ghana. Journal of Disaster Research, 9(4), 484-500.

Bolderdijk, J. W., Gorsira, M., Keizer, K., \& Steg, L. (2013). Values determine the (in) effectiveness of informational interventions in promoting pro-environmental behavior. PloS one, 8(12), e83911.

Brundtland, G. H., Khalid, M., Agnelli, S., Al-Athel, S., \& Chidzero, B. (1987). Our common future. New York, 8.

Byerlee, D., Stevenson, J., \& Villoria, N. (2014). Does intensification slow crop land expansion or encourage deforestation? Global Food Security, 3(2), 92-98.

Carstensen, L. L. (1992). Social and emotional patterns in adulthood: support for socioemotional selectivity theory. Psychology and aging, 7(3), 331.

Carstensen, L. L., Fung, H. H., \& Charles, S. T. (2003). Socioemotional selectivity theory and the regulation of emotion in the second half of life. Motivation and emotion, 27(2), 103-123.

Castro, P., Azul, A. M., Leal Filho, W., \& Azeiteiro, U. M. (2019). Climate change-resilient agriculture and agroforestry. Climate change-resilient agriculture and agroforestry.

Chand, R., Prasanna, P. L., \& Singh, A. (2011). Farm size and productivity: Understanding the strengths of smallholders and improving their livelihoods. Economic and Political Weekly, 5-11.

Coelho, F., Pereira, M. C., Cruz, L., Simões, P., \& Barata, E. (2017). Affect and the adoption of pro-environmental behaviour: A structural model. Journal of environmental Psychology, 54, 127-138.

Cohen, J. (1992). A power primer. Psychological bulletin, 112(1), 155.

Debonne, N. (2019). Climate Change and Land: an IPCC special report on climate change, desertification, land degradation, sustainable land management, food security, and greenhouse gas fluxes in terrestrial ecosystems: Chapter 1: Framing and Context.

Deininger, K., \& Byerlee, D. (2011). Rising global interest in farmland: can it yield sustainable and equitable benefits? : The World Bank.

Delia, J., \& Krasny, M. E. (2018). Cultivating positive youth development, critical consciousness, and authentic care in urban environmental education. Frontiers in psychology, 8, 2340.

DeSombre, E. R. (2017). Global environmental institutions: Taylor \& Francis.

Dittmer, L. D., \& Riemer, M. (2012). Fostering critical thinking about climate change: Applying community psychology to an environmental education project with youth.

Eckstein, D., Künzel, V., Schäfer, L., \& Winges, M. (2019). Global Climate Risk Index 2020. Bonn: Germanwatch.

English, T., \& Carstensen, L. L. (2015). Socioemotional selectivity theory. Encyclopedia of geropsychology, 1-6.

Fulford, S., \& Thompson, S. (2013). Youth community gardening programming as community development: The youth for ecoaction program in Winnipeg, Canada. Canadian journal of nonprofit and social economy research, 4(2).

Garrity, D. (2020). The upland ecosystem in the philippines: approach to sustainable farming and forestry. World, $21,22$.

Givens, J. E., \& Jorgenson, A. K. (2011). The effects of affluence, economic development, and environmental degradation on environmental concern: A multilevel analysis. Organization \& Environment, 24(1), 7491.

Grimmette, K. A. (2014). The impacts of environmental education on youth and their environmental awareness.

Gudmundsson, H., Marsden, G., \& Josias, Z. (2016). Sustainable transportation: Indicators, frameworks, and performance management.

Gupta, G. S. (2019). Land degradation and challenges of food security. Rev. Eur. Stud., 11, 63.

Hautier, Y., Tilman, D., Isbell, F., Seabloom, E. W., Borer, E. T., \& Reich, P. B. (2015). Anthropogenic environmental changes affect ecosystem stability via biodiversity. Science, 348(6232), 336-340.

Heaton, C., \& Burns, S. (2014). An evaluation of environmental impact assessment in Abu Dhabi, United Arab Emirates. Impact Assessment and Project Appraisal, 32(3), 246-251.

Kharkongor, E., \& Passah, P. (2012). Economic development and environmental degradation. In.

Kudryavtsev, A., Krasny, M. E., \& Stedman, R. C. (2012). The impact of environmental education on sense of place among urban youth. Ecosphere, 3(4), 1-15.

Larijani, M. (2010). Assessment of environmental awareness among higher primary school teachers. Journal of Human Ecology, 31(2), 121-124.

Laurance, W. F., Sayer, J., \& Cassman, K. G. (2014). Agricultural expansion and its impacts on tropical nature. Trends in ecology \& evolution, 29(2), 107-116. 
Li, W., MacBean, N., Ciais, P., Defourny, P., Lamarche, C., Bontemps, S., . . Peng, S. (2018). Gross and net land cover changes in the main plant functional types derived from the annual ESA CCI land cover maps (1992-2015).

Liu, X., Yu, L., Si, Y., Zhang, C., Lu, H., Yu, C., \& Gong, P. (2018). Identifying patterns and hotspots of global land cover transitions using the ESA CCI Land Cover dataset. Remote Sensing Letters, 9(10), 972-981.

Mason, L. R., Shires, M. K., Arwood, C., \& Borst, A. (2017). Social work research and global environmental change. Journal of the Society for Social Work and Research, 8(4), 645-672.

Min, D. (2020). The Effects of Age and Type of Imperative Statement on Behavioral Intention and Recall. Journal of Digital Convergence, 18(1), 53-58.

Montoneri, E., Mainero, D., Boffa, V., Perrone, D. G., \& Montoneri, C. (2011). Biochemenergy: A project to turn an urban wastes treatment plant into biorefinery for the production of energy, chemicals and consumer's products with friendly environmental impact. International journal of global environmental issues, 11(2), 170-196.

Nandwani, D. (2016). Organic farming for sustainable agriculture (Vol. 9): Springer.

Padi, F. K., Domfeh, O., Takrama, J., \& Opoku, S. (2013). An evaluation of gains in breeding for resistance to the cocoa swollen shoot virus disease in Ghana. Crop protection, 51, 24-31.

Pelusi, C., Altieri, P., Gambineri, A., Repaci, A., Cavazza, C., Fanelli, F., . . . Pasquali, R. (2019). Behavioral, socio-environmental, educational and demographic correlates of excess body weight in Italian adolescents and young adults. Nutrition, Metabolism and Cardiovascular Diseases, 29(3), 279-289.

Powlson, D. S., Stirling, C. M., Jat, M. L., Gerard, B. G., Palm, C. A., Sanchez, P. A., \& Cassman, K. G. (2014). Limited potential of no-till agriculture for climate change mitigation. Nature Climate Change, 4(8), 678.

Pudin, S. (2011). The informal environmental education value practices among adults in Sabah, Malaysia. Journal of Turkish Science Education, 8(1), 19-28.

Puthenkalam, J. J. (2016). Sustainable Development Goals as New Framework for Development From MDGs to SDGs. 上智経済論集, 61(1), 1-18.

Searchinger, T., Waite, R., Hanson, C., Ranganathan, J., Dumas, P., Matthews, E., \& Klirs, C. (2019). Creating a sustainable food future: A menu of solutions to feed nearly 10 billion people by 2050. Final report: WRI.

Sengupta, M., Das, J., \& Maji, P. K. (2010). Environmental awareness and environment related behaviour of twelfth grade students in Kolkata: Effects of stream and gender. Anwesa, 5(1), 1-8.

Shukla, P., Skeg, J., Buendia, E. C., Masson-Delmotte, V., Pörtner, H.-O., Roberts, D., . . van Diemen, S. (2019). Climate Change and Land: an IPCC special report on climate change, desertification, land degradation, sustainable land management, food security, and greenhouse gas fluxes in terrestrial ecosystems.

Song, X.-P. (2018). Global estimates of ecosystem service value and change: taking into account uncertainties in satellite-based land cover data. Ecological economics, 143, 227-235.

Song, Y., Qin, Z., \& Yuan, Q. (2019). The impact of eco-label on the young Chinese generation: The mediation role of environmental awareness and product attributes in green purchase. Sustainability, 11(4), 973.

Staples, A. F., Larson, L. R., Worsley, T. E., Green, G. T., \& Carroll, J. P. (2019). Effects of an art-based environmental education camp program on the environmental attitudes and awareness of diverse youth. The Journal of Environmental Education, 50(3), 208-222.

Van Cauwenberg, J., De Bourdeaudhuij, I., Clarys, P., De Geus, B., \& Deforche, B. (2019). Older adults' environmental preferences for transportation cycling. Journal of Transport \& Health, 13, 185-199.

Watete, P. W., Makau, W.-K., Njoka, J. T., AderoMacOpiyo, L., \& Mureithi, S. M. (2016). Are there options outside livestock economy? Diversification among households of northern Kenya. Pastoralism, 6(1), 3.

Willuweit, L. (2009). Promoting Pro-Environmental Behavior: An Investigation of the cross-cultural environmental behavior patterns. The Case of Abu Dhabi. In.

Wu, H., \& Mweemba, L. (2010). Environmental self-efficacy, attitude and behavior among small scale farmers in Zambia. Environment, Development and Sustainability, 12(5), 727-744.

Yucedag, C., Kaya, L. G., \& Cetin, M. (2018). Identifying and assessing environmental awareness of hotel and restaurant employees' attitudes in the Amasra District of Bartin. Environmental monitoring and assessment, 190(2), 60.

Zhang, L., Wang, J., \& You, J. (2015). Consumer environmental awareness and channel coordination with two substitutable products. European Journal of Operational Research, 241(1), 63-73.

Zheng, X., \& Wang, W. (2020). Whose Time Flies: Meaning in Life Influences Time Awareness. Journal of Adult Development, 1-9. 
Figures

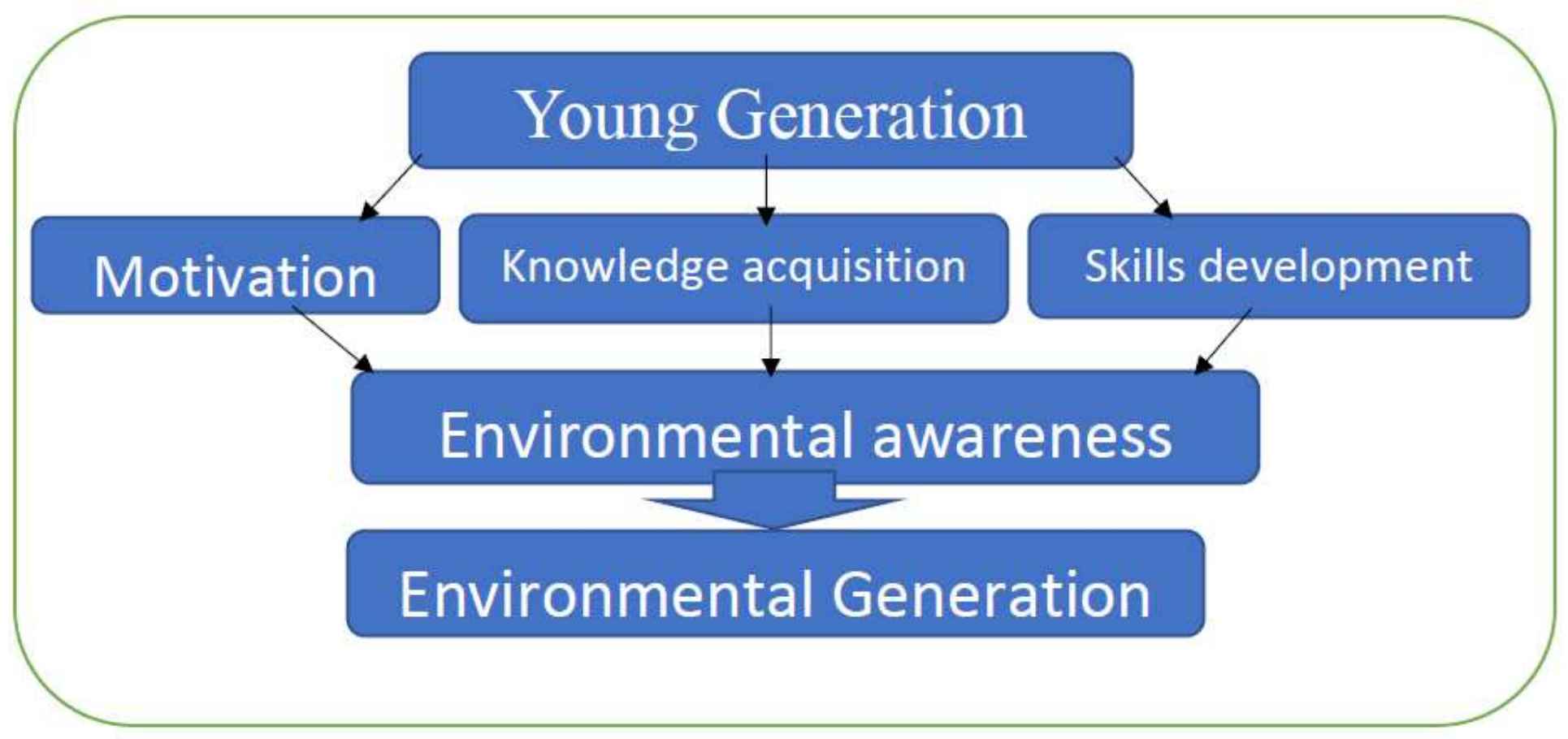

Figure 1

Environmental Generation framework 